\title{
Wild boar battues reduce crop damages in a protected area
}

\author{
Alberto GIMÉNEZ-ANAYA ${ }^{1,2 *}$, Juan HERRERO², Alicia GARCÍA-SERRANO ${ }^{1}$, Ricardo GARCÍA- \\ GONZÁLEZ ${ }^{3}$ and Carlos PRADA ${ }^{1}$
}

\begin{abstract}
${ }^{1}$ Ega Wildlife Consultants, Sierra de Vicort 31 1A, E-50003 Zaragoza, Spain; e-mail: egasl@arrakis.es
${ }^{2}$ Area of Ecology, Department of Agricultural and Environmental Sciences, Technical School, University of Zaragoza, E-22071 Huesca, Spain; e-mail: herreroj@unizar.es

${ }^{3}$ Pyrenean Institute for Ecology, Consejo Superior de Investigaciones Cientificas, Avda, Nuestra Señora de la Victoria, s/n, E-22700 Jaca, Spain; e-mail: rgarciag@ipe.csic.es
\end{abstract}

Received 11 February 2016; Accepted 14 June 2016

\begin{abstract}
Agricultural damages caused by wild boar Sus scrofa have given farmers a negative impression of protected areas and their management. To mitigate those damages and the social conflicts that they create, hunting battues involving experienced local hunters were used as a lethal population control method in a protected Iberian wetland. In the Ebro Sotos and Galachos Nature Reserve, Spain, between 1994 and 2011, 259 wild boars were culled during 476 battues. On average, battues involved six hunters and ten dogs, and culling efficiency (number of animals killed per animals seen during battues) was $39 \%$. The number of battues per year and the area of crop damages caused by wild boar were significantly negatively correlated, demonstrating battue efficiency to decrease damages. Moreover, intermittent population control through culling led to a substantial increase in the wild boar population, with an increase in crop damages. This underlines the importance of constant control. The numbers of hunters and dogs and the number of wild boar seen during battues were strongly correlated. To minimize the conflicts between farmers and the management of protected areas, we suggest that the inexpensive, volunteer-based population control program could be enhanced by incorporating stalking and mobile electric fences.
\end{abstract}

Key words: lethal control, agricultural damages, corn, hunters, dogs

\section{Introduction}

Conflicts between wildlife and human interests are a matter of concern worldwide (Woodroffe et al. 2005) as wildlife populations expand into anthropic environments with increasing human populations. The problems are particularly significant in poor countries, where farmers view agricultural damages caused by wildlife as their worst financial problem (NaughtonTreves \& Treves 2005). The wildlife-caused damages to crops in the Ebro Sotos and Galachos Nature Reserve, Spain, have created a significant conflict because of the characteristics of protected areas, which include crops that are highly attractive to wild boar (Neet 1995), the absence of measures by farmers to prevent damages, and a limited capacity to control the wild boar population. Since the beginning of agriculture, wildlife has caused damages to crops and livestock. A variety of techniques (scarecrows, snares, traps, cages, poison, vigilance, battues or drive hunts, waitings, changing crops etc.) have been used to address the problem (Honda et al. 2009, Massei et al. 2011) however, there is little or no scientific evidence of the effectiveness of these techniques (Woodroffe et al. 2005), even though wildlife-caused damages can cause significant economic harm, lead to farm failures, and the emigration of farmers (Treves 2008). Often, farmers spend a significant amount of resources to mitigate agricultural damages, primarily by using phyto-sanitary products that protect crops against fungi, insects, bacteria, viruses and, to a lesser extent, wild ungulates and other wildlife.

The number and distribution of wild boar worldwide has increased substantially (Vassant et al. 1987, Apollonio et al. 2010, Massei et al. 2011). This has made the species an important factor in the ecosystems in which it lives (Barrios-García \& Ballari 2012) because of its effects on the economy and the environment (Herrero et al. 2006). Wild boar damage crops (Herrero et al. 2006) and kill livestock (Pavlov $\&$ Hone 1982), or are suspected of doing so, which 
has a social impact (Herrero \& Fernández de Luco 2003). They also influence the natural environment through selective foraging (Giménez-Anaya et al. 2008) and by altering the soil through rooting (Bueno et al. 2013). They can even contribute to vehicle accidents (Lagos et al. 2012, Thurfjell et al. 2015). Specifically, wild boar damage crops by foraging, creating mud baths, trampling, rooting, resting, body scratching, and destroying irrigation systems. In the Ebro Sotos and Galachos Nature Reserve, wild boar fed on agricultural crops, mainly, corn Zea mays and had no effect on endangered species (e.g. birds) (Herrero et al. 2006). The Ebro Sotos and Galachos Nature Reserve sits within an agricultural landscape, where conflicts between foraging wild boar and agriculture are common. Concerns about the conservation of wildlife and the protection of natural habitats have led to policies such as the designation of protected areas (IUCN 2003), which can be hot spots of agricultural or livestock damages because they have features that make conservation a priority over some human activities (Leader-Williams \& Hutton 2005, Treves 2008). Since 1993, when the Ebro Sotos and Galachos Nature Reserve was established, wild boars have caused farmers substantial losses, which have precipitated illegal hunting (e.g. snaring, night shooting, and diesel baiting). Those factors, coupled with the existing important damages, lead to an increase in research, monitoring, control, and financial compensation to farmers (Nyhus et al. 2005, Osborne \& Hill 2005, Treves \& Naughton-Treves 2005, Herrero et al. 2006).

Hunter records are the basis of most of the studies on wild boar control and monitoring in Europe (Vassant et al. 1987, Rosell 1998, Sodeikat \& Pohlmeyer 2003, Geisser \& Reyer 2004, Schley et al. 2008, Keuling et al . 2010, Scillitani et al. 2010, Amici et al. 2012, Thurfjell et al. 2013). Information on hunting efficiency is useful for identifying trends in wild boar populations and aids in the design and evaluation of management measures (Keuling et al. 2008). Attempts to reduce the damages to crops have led to the development of research programs and the dispensation of significant amounts of money, as a means of reconciling hunting and agricultural interests (Vassant et al. 1987). Furthermore, wild boar hunting data are used to quantify population demographics (Zwickel 1980, Sáez-Royuela \& Tellería 1988, Rosell 1998, Herrero et al. 2008, Keuling et al. 2013) and evaluate population control measures (Hone 1994), even though the effectiveness and the factors that affect its development have not been evaluated thoroughly (Keuling et al. 2010).
The aim of our study was to assess the relationship between lethal population control based on battues and its effectiveness in reducing the damage caused to crops by wild boar. In several Mediterranean countries, battues are the main technique used to hunt wild boars (Spain, Portugal and Italy), which entails using dogs to drive the animals toward stationary shooters. Although the efficiency of lethal control methods has seldom been assessed, we hypothesized that wild boar battues are efficient to reduce damages.

\section{Study area}

The core of the study area was the Ebro Sotos and Galachos Nature Reserve, a protected area along the River Ebro near Saragossa, Aragon, Spain (Fig. 1). Battues were conducted in the relict riverine habitats within a portion (approximately $100 \mathrm{~km}$ ) of the River Ebro, which included the Ebro Sotos and Galachos Nature Reserve and adjacent areas. Most of the area is an intensively irrigated agroecosystem dedicated to corn, alfalfa Medicago sativa, winter cereals (wheat Triticum aestivum, barley Hordeum vulgare) and, to a lesser extent, fruit trees and vegetables. The irrigated land is surrounded by semi-arid habitats that have clay and gypsum soils and limited vegetation. The climate is sub-arid, with an average annual precipitation of $302 \mathrm{~mm}$ (range $=188-452 \mathrm{~mm}, 1994-2011$ ), most of which falls in May-June and October-November. Between 1994 and 2011, average annual minimum and maximum temperatures were $-9{ }^{\circ} \mathrm{C}$ and $43.1^{\circ} \mathrm{C}$, respectively. Reed Phragmites australis, tamarisk Tamarix africana, poplar Populus spp., willow Salix spp., and ash Fraxinus spp. predominate the small, isolated, relict riverine habitats. The largest riverine fragment is within the Ebro Sotos and Galachos Nature Reserve 1537 ha, a Special Protection Area for Birds because it is important for sedentary, migrant, and breeding birds such as the night heron Nycticorax nycticorax. In addition, it is a part of two European Sites of Community Importance. The Ebro Sotos and Galachos Nature Reserve is $40 \%$ riverine habitat, $35 \%$ agricultural land, and the remainder is water bodies, gravel, and roads.

Wild boars have been in the area since at least the 1960s and there are no physical barriers to prevent them from moving freely through the Ebro Sotos and Galachos Nature Reserve. The population has not received supplementary feeding. Crops are not fenced and farmers do not invest in wildlife damage prevention, except for agricultural pesticides, and mostly do not have insurance against damages caused by wildlife. The regional government is responsible 


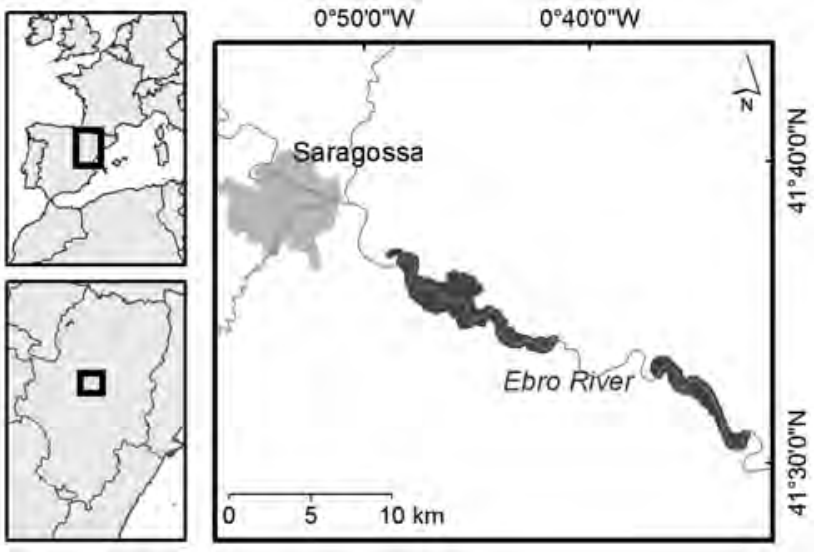

Fig. 1. Study area. The Ebro Sotos and Galachos Nature Reserve.

for the management of the Ebro Sotos and Galachos Nature Reserve and has a legal obligation to pay compensation to farmers for damages that occur within the protected area. Since 2001 some roe deer Capreolus capreolus appeared in the reserve. Their density can be considered very low during the whole study period.

\section{Material and Methods}

From 1994 to 2011, we quantified crops surface and the damages surface caused by wild boar, as well as the other habitats surface in the Ebro Sotos and Galachos Nature Reserve, Spain. In that time, some artificial reforestations of non-cultivated crops and natural re-vegetation of stony areas occurred in the area, which were included in the analysis of annual habitat availability. Each year, over a two-day period in May, all field crops were quantified visually, which provided an estimate of the area covered by each crop. Farmers reported agricultural damages caused by wild boar, which were quantified by an agricultural technical engineer hired by the regional government. Those data allowed an assessment of the crop species and the areas affected. The damage reports reflected an unknown number of crop damage events caused by wild boar.

From July to February (which avoided the bird breeding period), local, volunteer, non-professional hunters performed hunting battues with dogs to cull wild boar that had been observed in an earlier tracking survey, which increased hunting success. The study area was open to the public; therefore, hunters used shotguns, only. The dogs were scent (e.g. hounds, griffons) or grip (e.g. alano) breeds. Hunters completed a questionnaire about each battue. Hunting efficiency was the number of animals culled per the number of wild boar seen during each battue.
During each battue, hunters covered 30-50 ha of natural vegetation, which provided the only persistent refuge for wild boar within the area; consequently, the culling of wild boar in those refuges had a large effective area, most of which was foraging rather than refuge habitat (Herrero et al. 2006). Battues were performed inside and in the surroundings of the protected area.

To assess the factors that influenced the number of wild boar culled, we quantified the following 16 variables: month, municipality, inside or outside the Ebro Sotos and Galachos Nature Reserve, the area that was covered during the battue, tracking or not, weather (sunny, cloudy, rain, snow), number of hunters, number of dogs, number of wild boar seen, number of wild boar seen and not killed, number of male boar, number of female boar, number of yearlings, number of piglets, number of boar of unknown age and sex, number of foxes seen, which were included in a Principal Components Analysis (PCA). The statistical analyses included non-parametric tests (Mann-Whitney, Kruskal-Wallis, and Spearman) (Zar 1996) and multivariate principal components (R Core Team 2012).

\section{Results}

\section{Crops}

We recorded annual crop availability as the percentage of the protected area surface occupied by each crop species between 1994 and 2011. In the Ebro Sotos and Galachos Nature Reserve, during this period, the areas of corn $\left(r^{2}=0.31\right)$ and alfalfa $\left(r^{2}=0.31\right)$ crops decreased $(p=0.01)$, and winter cereals increased $\left(r^{2}=0.51, p<0.001\right.$; Spearman correlation test). In almost all years, alfalfa was the main crop; in one year, sorghum Sorghum bicolor, soya Glycine max, and fescue Festuca sp. were planted in one field each. Orchards and fruit trees occupied a small proportion of the area. After three years, areas that had been revegetated artificially were considered riverine habitats.

\section{Damages}

The damages produced by wild boar in the protected area crops were quantified between 1994 and 2011. During this period, the average number of reports of damages per year was four $(\mathrm{SD}=3.1)$, which affected four $(\mathrm{SD}=2.3)$ farmers, 12.5 ha $(\mathrm{SD}=7.1), 3.3 \%$ $(\mathrm{SD}=4.2)$ of crops, and $1.1 \%(\mathrm{SD}=1.4)$ of the Ebro Sotos and Galachos Nature Reserve.

\section{Culling}

Complete information was available for 411 of the 476 battues and 200 wild boars were culled. Within 
the Ebro Sotos and Galachos Nature Reserve, on average, $4.6(\mathrm{SD}=2)$ wild boar were culled during $11.6(\mathrm{SD}=5.4)$ battues per year. Hunting efficiency was $39 \%$ and, on average, 1.5 wild boar $(\mathrm{SD}=2)$ were seen per battue. At least one wild boar was seen or culled during $56 \%$ (maximum 13) and $31 \%$

Table 1. The PCA, variance and the importance of the culling success of wild boar battues $(n=453)$ conducted by volunteer hunters with dogs in the Ebro Sotos and Galachos Nature Reserve, Aragon, Spain, between 1994-2011.

\begin{tabular}{lcccc}
\hline Main components & MC1 & MC2 & MC3 & MC4 \\
\hline Component variances & 1.9372 & 1.4318 & 0.5322 & 0.0988 \\
Standard deviation & 1.3918 & 1.1966 & 0.7295 & 0.3173 \\
Variance proportion & 0.4843 & 0.3579 & 0.1330 & 0.0247 \\
Accumulated proportion & 0.4843 & 0.8422 & 0.9753 & 1.0000 \\
\hline
\end{tabular}

Table 2. Correlations between variables in the PCA of the culling success of wild boar battues $(n=453)$ conducted by volunteer hunters with dogs in the Ebro Sotos and Galachos Nature Reserve, Aragon, Spain, between 1994-2011.

\begin{tabular}{lclll}
\hline Main components & MC1 & MC2 & MC3 & MC4 \\
\hline Total wild boar seen & 0.6841 & 0.1734 & 0.0435 & 0.7071 \\
Wild boar seen & 0.6803 & 0.1942 & 0.0142 & -0.7065 \\
and not culled & & & & \\
Number of dogs & 0.2109 & -0.6712 & -0.7106 & 0.0043 \\
Number of hunters & 0.1573 & -0.6940 & 0.7021 & -0.0252 \\
\hline
\end{tabular}

Table 3. Damages, number of battues, and wild boar seen per battue in the Ebro Sotos and Galachos Nature Reserve, Aragon, Spain, between 1994 and 2011.

\begin{tabular}{cccc}
\hline Year & Battues & Wild boar per battue & Damages (ha) \\
\hline 1994 & 6 & 6.7 & 3.6 \\
1995 & 40 & 1.4 & 6.5 \\
1996 & 20 & 1.1 & 8.2 \\
1997 & 28 & 1.6 & 1.3 \\
1998 & 36 & 1.3 & 1.1 \\
1999 & 32 & 1.6 & 0.5 \\
2000 & 28 & 1.7 & 0.5 \\
2001 & 22 & 1.0 & 0.7 \\
2002 & 28 & 1.3 & 0.4 \\
2003 & 14 & 3.3 & 2.2 \\
2004 & 26 & 1.1 & 1.9 \\
2005 & 8 & 1.5 & 0 \\
2006 & 0 & 0 & 14.1 \\
2007 & 2 & 1.5 & 19.0 \\
2008 & 1 & 1.0 & 43.3 \\
2009 & 0 & 0 & 18.2 \\
2010 & 4 & 5.7 & 25.3 \\
2011 & 4 & 9.2 & 19.0 \\
\hline
\end{tabular}

(maximum 6) of the battues, respectively. On average, battues involved six hunters $(\mathrm{SD}=2.3)$ and $10(\mathrm{SD}=$ 2.3) dogs.

The number of wild boar seen did not differ significantly (Mann-Whitney $\mathrm{U}$ test $=-1.71, p=$ $0.087)$ between within $(n=161)$ and outside $(n=250)$ the Ebro Sotos and Galachos Nature Reserve. Culling pressure (number of hunters per battue) was higher (Mann-Whitney $\mathrm{U}$ test $=-8.6, p<0.001$ ), but hunting efficiency was lower (Mann-Whitney $U$ test $=-3.5$, $p=0.001$ ) within than they were outside the reserve. Culling efficiency did not differ significantly among years (Kruskal-Wallis $=11.7$, df $=11, p=0.39$ ), between the inside and outside of the protected area (Kruskal-Wallis $_{\text {outside }}=0, \mathrm{df}=11, p=0.52$; KruskalWallis $_{\text {inside } x}=5.1, \mathrm{df}=11, p=0.92$ ), or among months (Kruskal-Wallis $=15, \mathrm{df}=11, p=0.17$ ).

Between 1994 and 1995 (6.7-1.4 wild boar per battue), the number of wild boar seen decreased substantially $(-79 \%)$; thereafter, abundance fluctuated somewhat and, on average, the number of wild boar seen per battue was 1.4 (1.3-1.5 per battue).

\section{Efficiency of battues that used dogs}

In the PCA, number of wild boar seen during a battue, number of wild boar seen but not culled, number of dogs used in a battue, number of hunters, and number of foxes seen explained the most of the variance in the number of wild boar culled. The two principal components (MC1 and $\mathrm{MC} 2$ ) explained $84.2 \%$ of variance in the number of wild boar culled per battue (Table 1). The number of hunters and dogs that participated in the battues and the number of wild boar that were seen (and potentially, culled) was positively correlated. In addition, the number of wild boar seem was higher when the numbers of hunters and dogs per battue were higher too (Table 2).

\section{Culling and damages}

Between 1994 and 2011, we observed a positive relation between damages (ha), number of battues, and wild boar seen per battue in the Ebro Sotos and Galachos Nature Reserve. The number of battues and the area of damaged crops (Table 3) were inversely correlated (Spearman correlation coefficient: $\mathrm{r}=-0.683, p=0.002$, $\mathrm{n}=18$ ), which suggests that an increase in battues led to a reduction in agricultural damages.

\section{Discussion}

Battues are reliable for estimating wild boar abundance (Sáez-Royuela \& Tellería 1988), particularly, if trained dogs are used (Zwickel 1980). The culling efficiency 
of the battues in the Ebro Sotos and Galachos Nature Reserve was within the range of those reported in similar studies elsewhere in Iberia, even though the number of hunters per battue in our study was much lower than the number in other studies (Rosell 1998, Keulin et al. 2008). The dense vegetation in the Ebro Sotos and Galachos Nature Reserve, which existed because the restriction on the use of riparian habitats by livestock is most strongly enforced within the protected area, might have constrained culling efficiency. Dense vegetation reduces shooting accuracy and, because of the ban against the use of rifles, hunters cannot shoot from long distances, which increase the difficulty for hunters to cull wild boar within the reserve. Battues with dogs were efficient in reducing wild boar populations and the crop damages that they can cause. Typically, wild boars abandon beaten areas, temporally (Sodeikat \& Pohlmeyer 2003, Thurfjell et al. 2013) or permanently, if hunting pressure is high (Scillitani et al. 2010). The number of hunters and dogs is crucial to the success of the cull (Sodeikat \& Pohlmeyer 2003), as previously demonstrated by Rosell (1998). Although the Ebro Sotos and Galachos Nature Reserve has characteristics that made it highly vulnerable to agricultural damages caused by wildlife, damages were limited in the first part of the control period, but increased after the control was relaxed, which underscores the benefits of systematic control of the wild boar population. The overall impact of the damages was highest in the relaxed periods, which had a significant impact because of a delay in the disbursement of financial compensation. In the region, agricultural damages are persistent, inevitable, and require close attention because of their economic impact and the perceptions of the affected farmers, even if, in this case, they can be classified as high risk, but with a low vulnerability of farmers (Naughton-Treves \& Treves 2005). Despite changes in the annual crop composition and specific trends of some crops, battues succeeded in reducing the wild boar population and damages caused to crops.

Several interrelated factors underlie the conflict in the Ebro Sotos and Galachos Nature Reserve. The abundance of agricultural land inside the protected area, particularly, the availability of corn, which is a preferred food for wild boar (Herrero et al. 2006), makes the area highly attractive to wild boar. An increase in the amount of corn grown is a factor in the expansion of wild boar populations in some areas of Europe (Neet 1995). In addition, at the beginning of the control program in the Ebro Sotos and Galachos Nature Reserve, financial compensation for damages was paid quickly, however, in some years, compensation was delayed, which increased the dissatisfaction of the farmers. Crop damages caused by wildlife contribute to a negative perception of wildlife and protected areas among farmers, and financial compensation helps to mitigate this perception (Osborne \& Hill 2005). Wildlife population control, which reduces the tensions on farmers, has been less common, and has been followed by increases in the wild boar population and agricultural damages. Lethal population control improves the perceptions and attitudes of farmers and others towards the protected area and its wildlife, and lessens the conflict between humans and the species that causes the damage (Leader-Williams \& Hutton 2005), even if there is limited evidence that lethal or non-lethal population control reduces significantly the damages caused by wildlife to livestock (depredation) or crops (Osborne \& Hill 2005, Treves \& NaughtonTreves 2005, Woodroffe et al. 2005). The conditions in the Ebro Sotos and Galachos Nature Reserve make it highly vulnerable to damages by wild boar: following extirpation, wild boar repopulate the area; battues are the only active measure to prevent damage, crops provide an unlimited supply of high-quality food (Herrero et al. 2006) and a large refuge area, which was the largest along the river within at least $100 \mathrm{~km}$. Nyhus et al. (2005) suggested that financial compensation to farmers, along with proactive measures such as population control and incentives to change management are the only means of mitigating the conflict between man and wildlife. Thus, the problem is best addressed by the timely distribution of financial compensation, implementing effective population control; e.g. culling using battues (Geisser \& Reyer 2004) and stalking and improving agricultural management practices; e.g. using electric fences to protect crops (Geisser \& Reyer 2004, Honda et al. 2009) and growing alternative crops (Schley et al. 2008). This letal control experience decreases the conflict of wild boar damage to crops and supports the existence of the protected area and its environmental values.

\section{Acknowledgements}

This research was part of a long-term culling program in the Ebro Sotos and Galachos Nature Reserve that was implemented by the Regional Government of Aragon, which provided financial support. In addition, we thank the hunters, rangers, and technicians for their contributions to this study. Bruce MacWhirter improved the English. 


\section{Literature}

Amici A., Serrani F., Rossi C.M. \& Primi R. 2012: Increase in crop damage caused by wild boar (Sus scrofa L.): the "refuge effect". Agron. Sustain. Dev. 32: 683-692.

Apollonio M., Anderson R. \& Putman R. 2010: European ungulates and their management in the $21^{\text {st }}$ century. Cambridge University Press, Cambridge.

Barrios-García M.N. \& Ballari S.A. 2012: Impact of wild boar (Sus scrofa) in its introduced and native range: a review. Biol. Invasions 14: 2283-2300.

Bueno C.G., Azorín J., Gómez-García D. et al. 2013: Occurrence and intensity of wild boar disturbances, effects on the physical and chemical soil properties of alpine grasslands. Plant Soil 373: 243-256.

Geisser H. \& Reyer H.U. 2004: Efficacy of hunting, feeding, and fencing to reduce crop damage by wild boars. J. Wildlife Manage. 68: 939-946.

Giménez-Anaya A., Herrero J., Rosell C. et al. 2008: Food habits of wild boars (Sus scrofa) in a Mediterranean coastal wetland. Wetlands 28: 197-203.

Herrero J. \& Fernández de Luco D. 2003: Wild boars (Sus scrofa) in Uruguay: scavengers or predators? Mammalia 67: $485-491$.

Herrero J., García-Serrano A., Couto S. et al. 2006: Diet of wild boar Sus scrofa L. and crop damage in an intensive agroecosystem. Eur. J. Wildlife Res. 52: 245-250.

Herrero J., García-Serrano A. \& García-González R. 2008: Reproductive and demographic parameters in two Iberian wild boar Sus scrofa populations. Acta Theriol. 53: 355-364.

Honda T., Miyagawa Y., Ueda H. \& Inoue M. 2009: Effectiveness of newly designed electric fences in reducing crop damage by medium and large mammals. Mamm. Study 34: 13-17.

Hone J. 1994: Analysis of vertebrate pest control, $1^{\text {st }}$ ed. Cambridge University Press, Cambridge.

IUCN 2003: United Nations List of Protected Areas. Gland, Switzerland.

Keuling O., Baubet E., Duscher A. et al. 2013: Mortality rates of wild boar Sus scrofa L. in central Europe. Eur. J. Wildlife Res. 59: 805-814.

Keuling O., Lauterbach K., Stier N. \& Roth M. 2010: Hunter feedback of individually marked wild boar Sus scrofa L.: dispersal and efficiency of hunting in northeastern Germany. Eur. J. Wildlife Res. 56: 159-167.

Keuling O., Stier N. \& Roth M. 2008: How does hunting influence activity and spatial usage in wild boar Sus scrofa L.? Eur. J. Wildlife Res. 54: 729-737.

Lagos L., Picos J. \& Valero E. 2012: Temporal pattern of wild ungulate-related traffic accidents in northwest Spain. Eur. J. Wildlife Res. 58: 661-668.

Leader-Williams N. \& Hutton J. 2005: Does extractive use provide opportunities to reduce conflicts between people and wildlife? In: Woodroffe R., Thirgood S. \& Rabinowitz A. (eds.), People and wildlife: conflict or coexistence? Cambridge University Press, Cambridge: $140-162$.

Massei G., Roy S. \& Bunting R. 2011: Too many hogs? A review of methods to mitigate impact by wild boar and feral hogs. HumanWildlife Interactions 5: 79-99.

Naughton-Treves L. \& Treves A. 2005: Socio-ecological factors shaping local attitudes to wildlife in rural Africa. In: Woodroffe R., Thirgood S. \& Rabinowitz A. (eds.), People and wildlife: conflict and coexistence? Cambridge University Press, Cambridge: 253-277.

Neet C.R. 1995: Population dynamics and management of Sus scrofa in western Switzerland: a statistical modelling approach. J. Mt. Ecol. 3: 188-191.

Nyhus P.J., Osofsky S.A., Ferraro P. et al. 2005: Bearing the costs of human-wildlife conflict: the challenges of compensation schemes. In: Woodroffe R., Thirgood S. \& Rabinowitz A. (eds.), People and wildlife: conflict or coexistence? Cambridge University Press, Cambridge: 107-121.

Osborne F.V. \& Hill C.M. 2005: Techniques to reduce crop loss: human and technical dimensions in Africa. In: Woodroffe R., Thirgood S. \& Rabinowitz A. (eds.), People and wildlife: conflict or coexistence? Cambridge University Press, Cambridge: 72-85.

Pavlov R.M. \& Hone J. 1982: The behaviour of feral pigs, Sus scrofa, in flocks of lambing fines. Aust. Wildl. Res. 9: 101-109.

R Core Team 2012: R: a language and environment for statistical computing. R Foundation for Statistical Computing, Vienna. www.Rproject.org

Rosell C. 1998: Biologia i ecologia del senglar (Sus scrofa L., 1758) a dues poblacions del nordest ibèric. Aplicació a la gestió. Dissertation, MSc thesis, Departament de Biologia Animal, Universitat de Barcelona, Spain.

Sáez-Royuela C. \& Tellería J.L. 1988: Las batidas como método de censo en especies de caza mayor: aplicación al caso del jabalí (Sus scrofa L.) en la provincia de Burgos (Norte de España). Doñana Acta Vertebrata 15: 215-223.

Schley L., Dufrêne M., Krier A. \& Frantz A.C. 2008: Patterns of crop damage by wild boar (Sus scrofa) in Luxembourg over a 10-year period. Eur. J. Wildlife Res. 54: 589-599.

Scillitani L., Monaco A. \& Toso S. 2010: Do intensive drive hunts affect wild boar (Sus scrofa) spatial behaviour in Italy? Some evidences and management implications. Eur. J. Wildlife Res. 56: 307-318.

Sodeikat G. \& Pohlmeyer K. 2003: Escape movements of family groups of wild boar Sus scrofa influenced by drive hunts in Lower Saxony, Germany. Wildlife Biol. 9: 43-49.

Thurfjell H., Spong G. \& Ericsson G. 2013: Effects of hunting on wild boar Sus scrofa behaviour. Wildlife Biol. 19: 87-93.

Thurfjell H., Spong G., Olsson M. \& Ericsson G. 2015: Avoidance of high traffic levels results in lower risk of wild boar-vehicle accidents. Landsc. Urban Plann. 133: 98-104.

Treves A. 2008: The human dimensions of conflicts with wildlife around protected areas. In: Manfredo M.J., Vaske J.J., Brown P.J. et al. (eds.), Wildlife and society: the science of human dimensions. Island Press, Washington, D.C.: 262-278. 
Treves A. \& Naughton-Treves L. 2005: Evaluating lethal control in the management of human-wildlife conflict. In: Woodroffe R., Thirgood S. \& Rabinowitz A. (eds.), People and wildlife: conflict and coexistence. Cambridge University Press, Cambridge: 86-106.

Vassant J., Jullien J.M. \& Brandt S. 1987: Réduction des dégâts de sangliers sur ble et avoine en été. Etude de $1^{`}$ efficacite de $1^{`}$ epandage de maïs grain en forêt. Bull. Mens. Off. Natl. Chass. 113: 23-34.

Woodroffe R., Thirgood S. \& Rabinowitz A. 2005: People and wildlife: conflict or coexistence? Cambridge University Press, Cambridge.

Zar J.H. 1996: Biostatistical analysis. Prentice Hall, London.

Zwickel F.C. 1980: Use of dogs in wildlife biology. In: Schemnitz S.D. (ed.), Wildlife management techniques manual. The Wildlife Society, Washington D.C.: 531-536. 